\title{
Natural oxidation of black carbon in soils: Changes in molecular form and surface charge along a climosequence
}

\author{
Chih-Hsin Cheng ${ }^{\mathrm{a}, 1}$, Johannes Lehmann ${ }^{\mathrm{a}, *}$, Mark H. Engelhard ${ }^{\mathrm{b}}$ \\ ${ }^{a}$ Department of Crop and Soil Sciences, Cornell University, 909 Bradfield Hall, Ithaca, NY 14853, USA \\ ${ }^{\mathrm{b}}$ Environmental Molecules and Sciences Laboratory, Pacific Northwest National Laboratory, Richland, WA 99352, USA
}

Received 4 October 2007; accepted in revised form 14 January 2008; avilable online 26 January 2008

\begin{abstract}
The aim of this work was to investigate changes in molecular form and surface charge of black carbon (BC) due to longterm natural oxidation and to examine how climatic and soil factors affect $\mathrm{BC}$ oxidation. Black $\mathrm{C}$ was collected from 11 historical charcoal blast furnace sites with a geographic distribution from Quebec, Canada, to Georgia, USA, and compared to $\mathrm{BC}$ that was newly produced (new BC) using rebuilt historical kilns. The results showed that the historical $\mathrm{BC}$ samples were substantially oxidized after 130 years in soils as compared to new $\mathrm{BC}$ or $\mathrm{BC}$ incubated for one year. The major alterations by natural oxidation of $\mathrm{BC}$ included: (1) changes in elemental composition with increases in oxygen $(\mathrm{O})$ from $7.2 \%$ in new $\mathrm{BC}$ to $24.8 \%$ in historical $\mathrm{BC}$ and decreases in C from $90.8 \%$ to $70.5 \%$; (2) formation of oxygen-containing functional groups, particularly carboxylic and phenolic functional groups, and (3) disappearance of surface positive charge and evolution of surface negative charge after 12 months of incubation. Although time of exposure significantly increased natural oxidation of $\mathrm{BC}$, a significant positive relationship between mean annual temperature (MAT) and $\mathrm{BC}$ oxidation (O/C ratio with $r=0.83$;

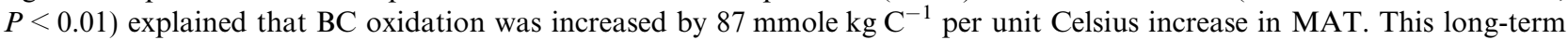
oxidation was more pronounced on $\mathrm{BC}$ surfaces than for entire particles, and responded 7-fold stronger to increases in MAT. Our results also indicated that oxidation of $\mathrm{BC}$ was more important than adsorption of non-BC. Thus, natural oxidation of $\mathrm{BC}$ may play an important role in the effects of $\mathrm{BC}$ on soil biogeochemistry.
\end{abstract}

(c) 2008 Elsevier Ltd. All rights reserved.

\section{INTRODUCTION}

Black carbon (BC) is the residue of incomplete combustion of biomass or fossil fuel. Black $\mathrm{C}$ is regarded as a chemically and biologically very stable $C$ pool and can persist in nature for long periods of time (Goldberg, 1985; Schmidt and Noack, 2000; Knicker, 2007). Charring biomass into $\mathrm{BC}$ therefore has been proposed as a way to divert $\mathrm{C}$ from a rapid biological $\mathrm{C}$ cycle into a slow geological C cycle (Kuhlbusch and Crutzen, 1995) and prompts investigations into actively managing $\mathrm{BC}$ as a means to

\footnotetext{
* Corresponding author.

E-mail address: CL273@cornell.edu (J. Lehmann).

${ }^{1}$ Present address: School of Forestry and Resource Conservation, National Taiwan University, Taipei 106, Taiwan.
}

sequester atmospheric carbon dioxide in soils (Lehmann et al., 2006; Lehmann, 2007a,b).

However, the long-term persistence of $\mathrm{BC}$ does not mean that the properties of $\mathrm{BC}$ remain unchanged after its deposition. Puri (1961) and Cheng et al. (2006) have reported rapid oxidation of $\mathrm{BC}$ in short-term incubations, whereby $\mathrm{BC}$ properties were altered through the formation of oxygen-containing functional groups. Oxidation of BC in soils has important implications for BC transport (Hockaday et al., 2006), erosion (Rumpel et al., 2006), stability (Bird et al., 1999; Czimczik and Masiello, 2007), and cation retention (Liang et al., 2006). Up to now, however, systematic research about the natural oxidation of $\mathrm{BC}$ in soils remains scarce and little is known about such aspects as to how fast or to what extent $\mathrm{BC}$ is oxidized.

In addition, because $\mathrm{BC}$ is ubiquitous and found in a wide variety of environments (Goldberg, 1985), it is essen- 
tial to investigate the differences of natural oxidation of $\mathrm{BC}$ under different climatic and soil regimes. We know that oxidation and decomposition of organic matter and litter typically increase with temperature (Davidson and Janssens, 2006). However, our understanding of the factors that affect natural oxidation of $\mathrm{BC}$ across different climates is limited. Biotic (Hamer et al., 2004) and abiotic processes, such as greater temperature (Puri, 1961; Cheng et al., 2006) and moisture (Billinge and Evans, 1984), may facilitate BC oxidation, while aggregate protection of BC (Glaser et al., 2000; Brodowski et al., 2005) promoted in fine-textured soils may reduce $\mathrm{BC}$ oxidation. To what extent these processes affect oxidation of $\mathrm{BC}$ in soils across a range of different environments is not known.

Due to the high recalcitrance of $\mathrm{BC}$, designing suitable laboratory or field experiments to investigate the long-term natural oxidation of $\mathrm{BC}$ is a challenge. In this study, we made use of $\mathrm{BC}$ samples from historical charcoal blast furnace sites in Quebec, Canada and the eastern U.S. These historical BC samples had similar deposition time, charring conditions and precursor wood. In addition, new BC made by the same method as the historical BC was collected to represent the "original" $\mathrm{BC}$ and was compared to the historical BC samples retrieved from soil. The wide geographic distribution of charcoal blast furnaces also made it possible to examine climatic and soil effects on historical BC samples. Our objective was to investigate changes in molecular form and surface charge of $\mathrm{BC}$ due to long-term natural oxidation along a climosequence. We hypothesized that long-term natural oxidation of $\mathrm{BC}$ leads to significant changes in both molecular form and surface charge and that the extent of $\mathrm{BC}$ oxidation is facilitated by greater temperature, moisture and biological activity but reduced by higher soil clay contents.

\section{MATERIALS AND METHODS}

\subsection{Historical and new $B C$ samples}

Historical BC samples were collected from the remnants of historical charcoal blast furnaces. The BC found in soils near these furnace sites was only deposited during a relatively short period around the 1870 s, as the rapid depletion of forest resources soon led to the replacement of charcoal furnaces by anthracite furnaces (Warren, 1973). The charcoal used for the blast furnaces was only produced from specific hardwoods. High specific gravity, crushing strength, and density were required, which was found in woods such as chestnut, hickory, oak, and sugar maple (Bining, 1938). In contrast to BC produced in forest fires, historical BC generated by colliers (charcoal workers) was of relatively uniform quality (Rolando, 1992).

In the 19th century, every eastern state in the U.S. (except for Delaware) had at least one furnace. In this study, eleven historical charcoal furnaces sites, spanning along a climosequence from Quebec (QC) to Georgia (GA), were selected. Some historical background and the climatic and soil characteristics of the selected furnace sites are shown in Table 1. Mean annual temperature (MAT), mean annual precipitation (MAP) and potential evapotranspiration

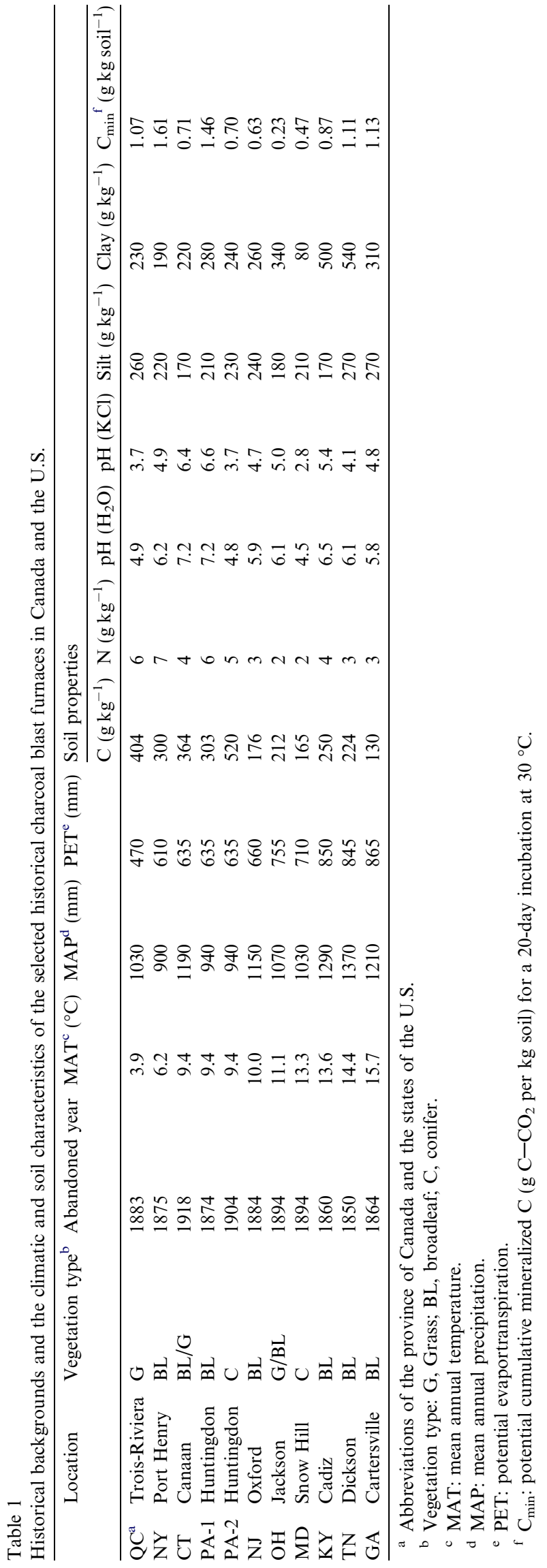


(PET) for each site were obtained from long-term climate data of the closest recording station. Effective precipitation was defined as MAP minus PET (MAP - PET) and was used to represent soil moisture conditions (Clark and Royall, 1995). Samples of soils containing high levels of BC (BC-containing soils) were collected from the areas where furnace workers temporarily stored the charcoal before charging it into the furnace. Dark black soil color and even large $\mathrm{BC}$ fragments are conspicuous in these BC-containing soils. For each soil, at least five soil cores were collected.

Since we focused on the natural oxidation of BC itself and intended to minimize any artifact caused by adhering soil or organic matter, more than 40 large fragments of $\mathrm{BC}$ with a size over $4 \mathrm{~mm}$, which were carefully picked from soil samples at a depth between 0.1 and $0.2 \mathrm{~m}$, were pooled and used in this research. Isolated $\mathrm{BC}$ fragments were repeatedly rinsed with distilled water until the electric conductivity was close to the background of distilled water. The $\mathrm{BC}$ fragments were then oven-dried at $70{ }^{\circ} \mathrm{C}$ for $24 \mathrm{~h}$ for further analyses.

In addition to the historical $\mathrm{BC}$ samples, new $\mathrm{BC}$ samples produced in Pennsylvania at the Hopewell Furnace National Historic Site $\left(\mathrm{New}-\mathrm{BC}_{\mathrm{HW}}\right)$ and at the Greenwood Furnace State Park (New-BC $\mathrm{GW}_{\mathrm{G}}$ ) were collected. Both of these new $\mathrm{BC}$ samples were made by the same traditional charcoal-making method, as done by charcoal workers in the 19th century. Charring conditions were carefully tended by the park rangers to obtain a high-quality metallurgical charcoal (Rolando, 1992). A mixture of white and red oak was charred at Hopewell $\left(\mathrm{NEW}-\mathrm{BC}_{\mathrm{HW}}\right)$, and only white oak wood was charred at Greenwood (NEW-BC $\mathrm{GW}_{\mathrm{GW}}$. The new BC samples are expected to have properties that were very close to the "original" status of the historical $\mathrm{BC}$ samples and were taken here to represent time-zero $\mathrm{BC}$ samples. The collected new BC samples were stored in glass jars purged with nitrogen gas to prevent further oxidation.

In order to provide the fundamental understanding of long-term natural oxidation of $\mathrm{BC}$, new $\mathrm{BC}$ from the Hopewell Furnace (New-BC $\mathrm{BW}_{\mathrm{HW}}$ ) was subjected to short-term aging experiments and coating with humic acid (HA; Sigma-Aldrich, St. Louis, Missouri, USA) for simulating short-term BC exposure in soils. In the aging experiments, $4 \mathrm{~mL}$ deionized water was added to $10 \mathrm{~g}$ of new $\mathrm{BC}$ and incubated in the dark inside $500-\mathrm{mL}$ glass jars at $30^{\circ} \mathrm{C}$ and $70^{\circ} \mathrm{C}$ for 12 months (denoted as BC30 and BC70) or at $70^{\circ} \mathrm{C}$ for 6 months (denoted as $\mathrm{BC} 70_{6 \mathrm{M}}$, only for XPS analysis). Glass jars were opened for aeration, as well as verification and adjustment of the water contents, every week for the first two months and then every other week during the rest of the incubation. It was expected that a higher temperature would enhance the degree of oxidation compared to a lower temperature (Cheng et al., 2006). No inoculant was added, as the oxidation during the first few months was expected to be dominated by abiotic processes (Cheng et al., 2006). In the experiment of coating BC with HA, HA solution was prepared by dissolving $200 \mathrm{mg}$ HA in $50 \mathrm{~mL} 0.1 \mathrm{~N} \mathrm{NaOH}$ solution, and deionized water was added to make up the $200 \mathrm{mg} \mathrm{L}^{-1} \mathrm{HA}$ solution. Forty milliliters of $200 \mathrm{mg} \mathrm{L}^{-1} \mathrm{HA}$ solution were added to $2 \mathrm{~g}$ of $\mathrm{BC}$ and shaken for 3 days. Throughout shaking, the $\mathrm{pH}$ of the BC slurry was adjusted by $1 \mathrm{~N} \mathrm{HCl}$ to a constant $\mathrm{pH}$ value of 6.8. After coating, the $\mathrm{BC}$ was washed with deionized water until the color of the filtrate was clear and reached a constant $\mathrm{pH}$ and then oven-dried at $70{ }^{\circ} \mathrm{C}$ for $24 \mathrm{~h}$. The dissolved C of filtrates for both BC slurry and control HA solution was measured by a carbon analyzer (Model 1010 TOC Analyzer, OI Analytical, Texas) and the difference of dissolved $\mathrm{C}$ concentration was assumed to be the adsorption of HA. In this study, $2.52 \mathrm{mg} \mathrm{HA}$ were sorbed to $1 \mathrm{~g}$ of $\mathrm{BC}$.

\subsection{Analyses of $B C$ fragments and soils}

Total $\mathrm{C}$ and nitrogen $(\mathrm{N})$ concentrations of $\mathrm{BC}$ fragments were measured by dry combustion using a Europa ANCA GSL sample combustion unit (PDZ Europa, Crewe, $\mathrm{UK})$. Hydrogen $(\mathrm{H})$ concentrations were measured after BC sample conversion to $\mathrm{H}_{2}$ at $1400{ }^{\circ} \mathrm{C}$ over glassy $\mathrm{C}$ (Hekatech TCEA, Hekatech GmbH, Wegberg, Germany). Ash content was analyzed by the loss of weight via combusting the $\mathrm{BC}$ sample at $550{ }^{\circ} \mathrm{C}$ for $2 \mathrm{~h}$. Oxygen $(\mathrm{O})$ concentrations were determined by difference. Elemental composition of $\mathrm{C}, \mathrm{N}, \mathrm{H}$, and $\mathrm{O}$ of $\mathrm{BC}$ samples were presented on a dry ash-free basis.

In addition to the $\mathrm{BC}$ fragments, the properties of $\mathrm{BC}$ containing soils were measured as well. Total $\mathrm{C}$ and $\mathrm{N}$ concentrations of the $\mathrm{BC}$-containing soils were measured by dry combustion. Soil texture was measured on adjacent soils which contained no visible BC particles using the hydrometer method. Potential soil biological activity was evaluated by measuring the cumulative soil $\mathrm{C}$ mineralization rate of the BC-containing soils over a 20-day incubation period. The incubation was carried out at the same temperature of $30^{\circ} \mathrm{C}$ for all soils in the dark under $60 \%$ water holding capacity. The evolved $\mathrm{CO}_{2}$ was trapped in $10 \mathrm{~mL} 0.1 \mathrm{~N} \mathrm{NaOH}$, which is placed in a small vessel inside the incubation jar, and measured by titration of the $\mathrm{NaOH}$ solution with standard $0.1 \mathrm{~N}$ $\mathrm{HCl}$ in excess of $\mathrm{BaCl}_{2}$. The mineralized $\mathrm{CO}_{2}$ was displayed per unit soil $\left(\mathrm{g} \mathrm{C}-\mathrm{CO}_{2} \mathrm{~kg}\right.$ soil $\left.^{-1}\right)$. Soil $\mathrm{pH}$ was measured in 1:2.5 (w/v) ratio with $\mathrm{H}_{2} \mathrm{O}$ or $1 \mathrm{~N} \mathrm{KCl}$ solution. In this study, $\mathrm{pH}$ values in $\mathrm{BC}$ fragments $(1: 20 \mathrm{w} / \mathrm{v}$ ratio) were close to the corresponding $\mathrm{pH}$ values in $\mathrm{BC}$ containing soils.

\subsection{X-ray photoelectron spectroscopy (XPS)}

XPS measurements were conducted at the Wiley Environmental Molecular Sciences Laboratory using a Physical Electronics Quantum 2000 scanning ESCA Microprobe (Physical Electronics GmbH, Ismaning, Germany). The 98-W, 107- $\mu \mathrm{m}$ diameter X-rays were rastered over a 1.4 by $0.2 \mathrm{~mm}$ rectangle on the sample. The XPS survey scan spectra in the $1000-0 \mathrm{eV}$ binding energy range were recorded with a pass energy of $50 \mathrm{eV}$. High-energy resolution scan spectra of $\mathrm{C} 1 \mathrm{~s}$ were recorded in $0.2 \mathrm{eV}$ steps with a pass energy of $20 \mathrm{eV}$. Low energy electrons and Ar ions were conducted for specimen neutralization in each measurement. In this study, XPS measurements were performed on both intact BC particles and ground BC samples repre- 
senting the surface and entire particle, respectively (Cheng et al., 2006). Here, unwashed intact BC particles of 1$2 \mathrm{~mm}$ in size were used. The approximate amount of $\mathrm{O}$ bound to $\mathrm{C}(\mathrm{Oc})$ was obtained by subtraction of the contribution of inorganic $\mathrm{O}$ from total $\mathrm{O}$ contents, and was calculated using the following equation (Brodowski et al., 2005):

$$
\begin{aligned}
\mathrm{Oc}= & \mathrm{O}(\text { total } \mathrm{O})-(\mathrm{Na} * 0.5+\mathrm{Mg} * 1+\mathrm{Al} * 1.5 \\
& +\mathrm{Si} * 2+\mathrm{K} * 0.5+\mathrm{Ca} * 1+\mathrm{Fe} * 1.176)
\end{aligned}
$$

For the narrow scan C1s spectra, the spectra were deconvoluted by a non-linear least squares curve fitting program (XPSPEAK Version 4.1 software) with a Gaussian-Lorentzian mix function and Shirley background subtraction. The $\mathrm{C} 1 \mathrm{~s}$ binding energy for $\mathrm{C}=\mathrm{C}, \mathrm{C}-\mathrm{C}$ and $\mathrm{C}-\mathrm{H}$ was assigned to $284.6 \mathrm{eV}$. The shifts of the $\mathrm{C} 1 \mathrm{~s}$ binding energy were defined for $1.6 \mathrm{eV}$ as $\mathrm{C}-\mathrm{O}$, for $3.0 \mathrm{eV}$ as $\mathrm{C}=\mathrm{O}$, and for $4.5 \mathrm{eV}$ as $\mathrm{COO}$ (Proctor and Sherwood, 1982). In this experiment, new $\mathrm{BC}$ and seven historical BC samples, including QC, NY, CT, OH, MD, TN, and GA, were measured.

\subsection{Fourier transform infrared (FTIR)}

The spectra of FTIR absorbance were recorded between 400 and $4000 \mathrm{~cm}^{-1}$ with a Matteson Model 5020 FTIR Spectrometer (Madison, Wisconsin, USA). Potassium bromide $(\mathrm{KBr})$ pellets containing $0.3 \%$ of finely ground $\mathrm{BC}$ powder were prepared and scanned. One hundred scans from 400 to $4000 \mathrm{~cm}^{-1}$ were averaged with a resolution of $4 \mathrm{~cm}^{-1}$.

In addition to the FTIR measurement of all BC samples, a series of $\mathrm{pH}$ adjustments of the QC and CT BC samples were also measured by FTIR. Basic and acidic QC and CT BC samples were obtained by adding $0.1 \mathrm{~N} \mathrm{HCl}$ and $\mathrm{KOH}$ to the $\mathrm{BC}$ suspension $(1: 200 \mathrm{w} / \mathrm{v}$ ratio). The $\mathrm{pH}$ of the BC suspension was determined after shaking the suspension for $24 \mathrm{~h}$ and was applied to represent the adjusted $\mathrm{pH}$ of $\mathrm{BC}$. Black $\mathrm{C}$ samples with $\mathrm{pH}$ adjustments were separated by centrifugation and dried at $70{ }^{\circ} \mathrm{C}$ for $24 \mathrm{~h}$.

\subsection{Surface charge characteristics}

The surface charge of BC samples was assessed by the "index" or "indifferent" ion adsorption method (Uehara and Gillman, 1981; Chorover et al., 2006). A KCl electrolyte $(0.01 \mathrm{~N})$ was used in the present study, in which both $\mathrm{K}$ and $\mathrm{Cl}$ ions were assumed to be bound by non-specific adsorption. Briefly, the method comprised three main steps: (1) preparation of a $\mathrm{KCl}$ saturated $\mathrm{BC}$ paste, (2) adjustment of the $\mathrm{pH}$ of $\mathrm{BC}$ to a range of $\mathrm{pH}$ values under the same ionic strength, (3) displacement of adsorbed $\mathrm{K}$ and $\mathrm{Cl}$ by $1 \mathrm{~N}$ ammonium nitrate.

(1) $\mathrm{BC}$ saturation by $\mathrm{KCl}$ : Two grams $\mathrm{BC}$ were suspended in $20 \mathrm{~mL}$ of $1 \mathrm{~N} \mathrm{KCl}$ in $30 \mathrm{~mL}$ centrifuge tubes for end-over-end shaking for $1 \mathrm{~h}$. The suspension was then centrifuged at 48,000 RCF for $20 \mathrm{~min}$. The supernatant was carefully aspirated and discarded. The remaining $\mathrm{BC}$ paste was repeatedly suspended in $0.2 \mathrm{~N} \mathrm{KCl}$ and $0.01 \mathrm{~N} \mathrm{KCl}$ for one and two times, respectively. After the last centrifugation step, the remaining $\mathrm{BC}$ paste was transferred to a petri dish, sealed with paraffin, and stored at $4{ }^{\circ} \mathrm{C}$. The water content of the $\mathrm{BC}$ paste was measured by transferring a small portion of the $\mathrm{BC}$ paste to an aluminum dish and drying it at $105^{\circ} \mathrm{C}$ for $24 \mathrm{~h}$.

(2) $\mathrm{pH}$ adjustment: Around $0.15 \mathrm{~g}$ of the $\mathrm{BC}$ paste (on a dry weight basis) was transferred to $30 \mathrm{~mL}$ preweighed centrifuge tubes. Twenty milliliters $0.01 \mathrm{~N}$ $\mathrm{KCl}$, adjusted by $0.1 \mathrm{~N} \mathrm{KOH}$ or $\mathrm{HCl}$ across an adequate $\mathrm{pH}$ range under the same ionic strength, was added to a batch of the tubes. The tubes were shaken for $12 \mathrm{~h}$ and then centrifuged at 48,000 RCF for $20 \mathrm{~min}$. The supernatant was carefully aspirated to a $30 \mathrm{~mL}$ bottle and the $\mathrm{pH}$ value was measured immediately. The concentrations of $\mathrm{K}$ and $\mathrm{Cl}$ in the supernatant were measured as well. The tubes with $\mathrm{BC}$ and entrained solution $(0.01 \mathrm{~N} \mathrm{KCl})$ were weighed to calculate the mass of entrained $\mathrm{K}$ and $\mathrm{Cl}$ inside the centrifuge tubes.

(3) Displacement of adsorbed $\mathrm{K}$ and $\mathrm{Cl}$ by ammonium nitrate: Twenty milliliters $1 \mathrm{~N}$ ammonium nitrate were added to the centrifuge tubes which were shaken for $1 \mathrm{~h}$ to displace the adsorbed $\mathrm{K}$ and $\mathrm{Cl}$ ions. After centrifuging at 48,000 RCF for $20 \mathrm{~min}$, the solution was aspirated into $60 \mathrm{~mL}$ bottles. The displacement by ammonium nitrate was repeated twice and the extracts pooled. The concentration of $\mathrm{K}$ and $\mathrm{Cl}$ extracted by $1 \mathrm{~N}$ ammonium nitrate solution was measured. Potassium ions were measured by atomic absorption spectrometry (Instrumentation Laboratory, Lexington, Massachusetts, USA) and $\mathrm{Cl}$ ions were measured by a chloridometer (Haake Buchler Instruments, Saddle Brook, New Jersey, USA).

The adsorption of $\mathrm{K}$ and $\mathrm{Cl}$ ions by $\mathrm{BC}$ was calculated using the following equation:

$\mathrm{K}$ or $\mathrm{Cl}=n_{\mathrm{K}}\left(\right.$ or $\left.n_{\mathrm{Cl}}\right)-M_{\mathrm{entr}} m_{\mathrm{k}}\left(\right.$ or $\left.M_{\mathrm{entr}} m_{\mathrm{cl}}\right)$

where $n_{\mathrm{K}}$ or $n_{\mathrm{Cl}}$ was the $\mathrm{K}$ and $\mathrm{Cl}$ determined in $1.0 \mathrm{~N}$ ammonium nitrate (in step 3). $M_{\text {entr }}$ denotes the mass of entrained solution left in the centrifuge tube before ammonium nitrate replacement (in step 2), and $m_{\mathrm{K}}$ or $m_{\mathrm{Cl}}$ denotes the concentration of $\mathrm{K}$ or $\mathrm{Cl}$ ions in the supernatant (in step 2). Surface positive charge was defined as the adsorption of anions $\left(\mathrm{Cl}^{-}\right)$, and surface negative charge was the adsorption of cations $\left(\mathrm{K}^{+}\right)$.

In this study, surface charge of $\mathrm{BC}$ was represented on a $\mathrm{C}$ basis (mmole $\mathrm{kg} \mathrm{C}^{-1}$ ). A quadratic model was used for fitting surface charge and $\mathrm{pH}$. Point of zero net charge (PZNC) was defined as the $\mathrm{pH}$ that had an equal amount of surface positive and negative charge. Anion exchange capacity (AEC) was defined as the amount of net surface positive charge at $\mathrm{pH} 3.5$; effective cation exchange capacity (ECEC) was defined as the amount of surface negative charge at $\mathrm{BC}$ 's $\mathrm{pH}$ (under $\mathrm{H}_{2} \mathrm{O}$ or $1 \mathrm{~N} \mathrm{KCl}$ suspension); and potential cation exchange capacity (PCEC) was defined as the amount of surface negative charge at $\mathrm{pH} 7$. 


\subsection{Relationships between $\mathrm{BC}$ oxidation and the climatic and soil characteristics}

Simple linear correlations between BC oxidation and the climatic and soil characteristics were conducted for examining if the properties of historical BC were related to climatic and soil characteristics. Stepwise multivariate regressions (SAS 9.1, Proc Reg, SAS Institute, Cary, NC) confirmed the observations of these individual correlations. The examined parameters of $\mathrm{BC}$ oxidation included elemental $\mathrm{C}$ and $\mathrm{O}$ concentrations, atomic $\mathrm{O} / \mathrm{C}$ ratios, $\mathrm{PCEC}$, and ECEC at $\mathrm{pH}_{\mathrm{H}_{2} \mathrm{O}}$ and $\mathrm{pH}_{\mathrm{KCl}}$. The examined climatic and soil characteristics included MAT, MAP, effective precipitation (MAP - PET), soil $\mathrm{pH}$, clay content, soil $\mathrm{C} / \mathrm{N}$ ratio, and soil mineralized $\mathrm{C}$ as a proxi for microbial activity. Since the data from the XPS and FTIR measurements were qualitative rather than quantitative, these results were not included in the correlation model. In a separate study, it was shown that the $\mathrm{BC}$-containing soils under conifer vegetation had higher $\mathrm{C}$ storage than the soils under broadleaf or grass vegetation (Cheng, 2008). Therefore, correlations between $\mathrm{BC}$ oxidation and the climatic and soil characteristics were only conducted for the sites under broadleaf and grass vegetation.

\section{RESULTS}

\subsection{Elemental composition and molecular structure}

New BC contained high amounts of $\mathrm{C}(90.8 \%)$ and low amounts of $\mathrm{O}(7.2 \%)$ and $\mathrm{H}(1.7 \%)$ (Fig. 1a and Table EA1). With coating of HA (BC-HA), very small decreases in $\mathrm{C}$ and increases in $\mathrm{O}$ were found, while aging of $\mathrm{BC}$ by incubation for 12 months showed a slightly higher reduction in $\mathrm{C}$ concentrations and increases in $\mathrm{O}$ and $\mathrm{H}$ concentrations. Carbon concentrations were reduced to $88.2 \%$ and $85.8 \%$, while $\mathrm{O}$ concentrations increased to $9.2 \%$ and $10.6 \%$ and $\mathrm{H}$ concentrations to $2.4 \%$ and $3.4 \%$ for $\mathrm{BC}$ incubated at $30{ }^{\circ} \mathrm{C}(\mathrm{BC} 30)$ and $70{ }^{\circ} \mathrm{C}(\mathrm{BC} 70)$, respectively. In contrast, all historical $\mathrm{BC}$ samples displayed substantially decreased amounts of $\mathrm{C}$ and increased amounts of $\mathrm{O}$ and $\mathrm{H}$. The average $\mathrm{C}$ concentration of historical $\mathrm{BC}$ samples was $70.5 \%$, and average $\mathrm{O}$ and $\mathrm{H}$ concentrations were $24.8 \%$ and $4.5 \%$. Natural oxidation of BC concomitantly increased atomic $\mathrm{O} / \mathrm{C}$ ratios, from 0.06 in new $\mathrm{BC}$ to 0.26 in historical $\mathrm{BC}$, and $\mathrm{H} / \mathrm{C}$ ratios, from 0.23 to 0.76 (Fig. $1 \mathrm{~b}$ and Table EA1).

Except for BC-HA which demonstrated comparatively lower $\mathrm{C}$ and higher $\mathrm{O}$, the elemental compositions obtained from XPS measurements had similar trends compared to the elemental analyses, in that new $\mathrm{BC}$ had higher $\mathrm{C}$ and lower $\mathrm{O}$ concentrations compared to historical BC (Table 2). High-resolution XPS C1s spectra further indicated that the increases of $\mathrm{O}$ were due to the formation of oxygen-containing functional groups. Our data also showed that higher oxygen-containing functional groups, as well as lower $\mathrm{C}$ and $\mathrm{O}$ contents, were found on $\mathrm{BC}$ surfaces compared to entire particles for the historical BC samples and the sum of all oxygen-containing functional groups of the historical BC samples
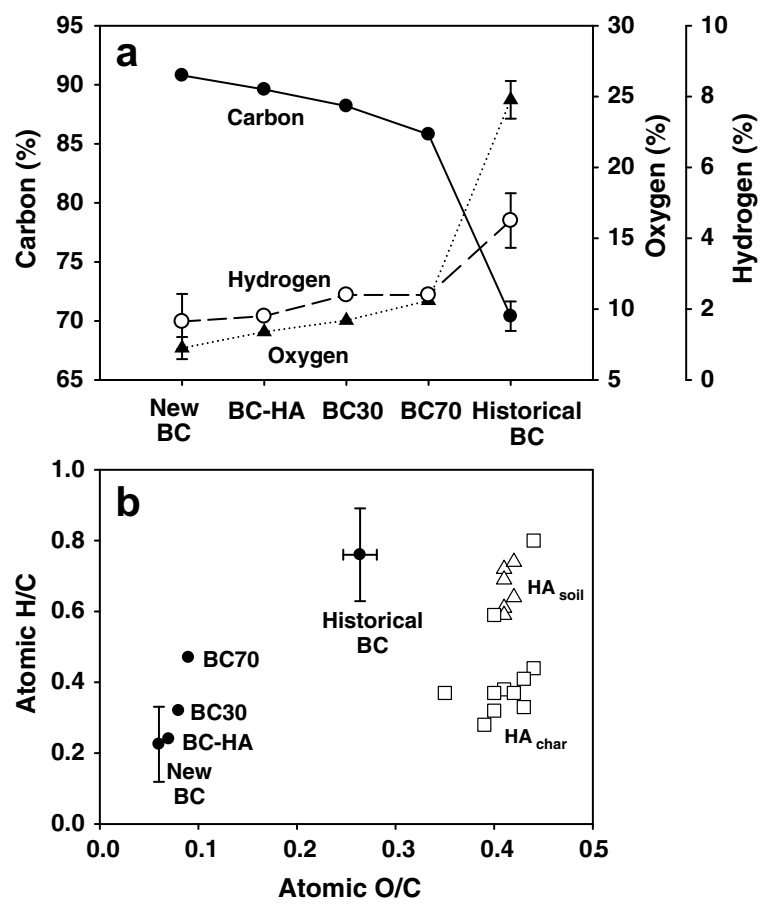

Fig. 1. (a) Elemental composition of carbon, oxygen and hydrogen; (b) atomic O/C versus $\mathrm{H} / \mathrm{C}$ ratios (van Krevelen Diagram) of new $(n=2)$ and historical BC samples $(n=11)$. BC-HA represents the coating of new $\mathrm{BC}$ with $\mathrm{HA}$. $\mathrm{BC} 30$ and $\mathrm{BC} 70$ denote aging of new $\mathrm{BC}$ under 30 and $70^{\circ} \mathrm{C}$ for 12 months. $\mathrm{HA}_{\text {soil }}$ (open triangles, Haumaier and Zech, 1995) and $\mathrm{HA}_{\text {char }}$ (open squares, Trompowsky et al., 2006) represent the humic acid extracted from BC-rich soils and charcoal. Error bars represent 1 standard deviation.

were two times higher than that of surfaces and $60 \%$ higher than that of the entire particles of new $\mathrm{BC}$.

The FTIR spectra of new BC, as well as BC-HA and BC30, showed a "flat" pattern and no bands were observed (Fig. 2). With progressive oxidation, the bands of functional groups evolved. The spectrum of BC70 showed discernable bands at wavenumbers of $1700 \mathrm{~cm}^{-1}$ and $1600 \mathrm{~cm}^{-1}$. All historical BC displayed well resolved FTIR spectra (Fig. 2), with major bands at wavenumbers of 3400 , $1700,1600,1585,1380$, and $1260 \mathrm{~cm}^{-1}$. The band at $3400 \mathrm{~cm}^{-1}$ was assigned to $\mathrm{OH}$ bonds, $1700 \mathrm{~cm}^{-1}$ to carboxylic acid groups, $1600 \mathrm{~cm}^{-1}$ to molecular vibration of ring stretching in $\mathrm{C}=\mathrm{C}, 1585$ and $1380 \mathrm{~cm}^{-1}$ to carboxylate, and $1260 \mathrm{~cm}^{-1}$ to phenolic acid functional $(\mathrm{C}-\mathrm{O})$ and COOH groups (Starsinic et al., 1983; Guo and Bustin, 1998; Jia and Thomas, 2000).

Detailed FTIR measurements of QC and CT BC under different $\mathrm{pH}$ adjustments indicated that most bands of historical $\mathrm{BC}$ samples were $\mathrm{pH}$ dependent (Fig. 3). The band intensities at 1700 and $1260 \mathrm{~cm}^{-1}$ decreased with increasing $\mathrm{pH}$; whereas the band intensities at 1585 and $1380 \mathrm{~cm}^{-1}$ increased with increasing $\mathrm{pH}$. With the rise of $\mathrm{pH}$ values, the aromatic $\mathrm{C}=\mathrm{C}$ band intensity at $1600 \mathrm{~cm}^{-1}$ was obscured by the increasing intensity of carboxylate bands at $1585 \mathrm{~cm}^{-1}$. These results ascertained our band assignments. 
XPS widescan of the atomic compositions of carbon and oxygen and the deconvolution of Cls narrow scan spectra of new and historical BC samples

\begin{tabular}{|c|c|c|c|c|c|c|c|c|c|c|c|c|c|c|c|c|}
\hline & \multicolumn{8}{|c|}{ Surface analyses } & \multicolumn{8}{|c|}{ Bulk analyses } \\
\hline & \multirow[t]{2}{*}{ C $(\%)$} & \multirow[t]{2}{*}{$\mathrm{Oc}^{\mathrm{a}}(\%)$} & \multirow[t]{2}{*}{$\mathrm{Oc} / \mathrm{C}$} & \multicolumn{5}{|c|}{ C1s composition $(\%)^{\mathrm{b}}$} & \multirow[t]{2}{*}{ C $(\%)$} & \multirow[t]{2}{*}{ Oc $(\%)$} & \multirow[t]{2}{*}{$\mathrm{Oc} / \mathrm{C}$} & \multicolumn{5}{|c|}{ C1s composition $(\%)^{\mathrm{b}}$} \\
\hline & & & & $\mathrm{C}=\mathrm{C}$ & Sum $^{\mathrm{c}}$ & $\mathrm{C}-\mathrm{O}$ & $\mathrm{C}=\mathrm{O}$ & $\mathrm{COO}$ & & & & $\mathrm{C}=\mathrm{C}$ & Sum $^{\mathrm{c}}$ & $\mathrm{C}-\mathrm{O}$ & $\mathrm{C}=\mathrm{O}$ & $\mathrm{COC}$ \\
\hline \multicolumn{17}{|l|}{ New $B C$} \\
\hline New-BC ${ }_{H W}$ & 91.3 & 8.7 & 0.10 & 77.5 & 22.3 & 15.4 & 3.6 & 3.3 & ND & ND & ND & ND & ND & ND & ND & ND \\
\hline New-BC $\mathrm{GW}_{\mathrm{GW}}$ & 90.2 & 9.6 & 0.11 & 77.2 & 22.9 & 14.5 & 4.5 & 3.9 & ND & ND & ND & ND & ND & ND & ND & ND \\
\hline BC-HA & 84.0 & 14.5 & 0.17 & 71.0 & 28.9 & 19.3 & 4.6 & 5.0 & ND & ND & ND & ND & ND & ND & ND & ND \\
\hline $\mathrm{BC} 70_{6 \mathrm{M}}{ }^{\mathrm{d}}$ & 86.5 & 13.0 & 0.15 & 71.2 & 28.8 & 19.9 & 4.1 & 4.8 & ND & ND & ND & ND & ND & ND & ND & ND \\
\hline \multicolumn{17}{|c|}{ Historical $B C$} \\
\hline $\mathrm{QC}$ & 61.1 & 30.5 & 0.50 & 50.5 & 49.5 & 25.9 & 17.0 & 6.6 & 77.3 & 21.1 & 0.27 & 67.8 & 32.2 & 16.1 & 8.8 & 7.3 \\
\hline NY & 59.1 & 29.5 & 0.50 & 46.4 & 53.6 & 27.5 & 21.2 & 4.9 & 70.8 & 25.9 & 0.37 & 58.1 & 41.9 & 23.1 & 12.2 & 6.6 \\
\hline $\mathrm{CT}$ & ND & ND & ND & ND & ND & ND & ND & ND & 69.7 & 25.8 & 0.37 & 61.4 & 38.6 & 17.6 & 12.2 & 8.8 \\
\hline $\mathrm{OH}$ & 33.0 & 26.9 & 0.82 & 55.5 & 44.5 & 20.8 & 18.7 & 5.0 & 68.8 & 26.6 & 0.39 & 67.6 & 32.2 & 15.0 & 11.0 & 6.2 \\
\hline MD & 51.3 & 27.4 & 0.54 & 49.3 & 50.7 & 28.1 & 16.4 & 6.2 & 75.0 & 23.5 & 0.31 & 65.2 & 34.8 & 17.1 & 10.1 & 7.6 \\
\hline $\mathrm{TN}$ & 278 & 25.9 & 0.92 & 49.8 & 50.1 & 26.8 & 19.3 & 4.0 & 72.2 & 24.2 & 0.34 & 69.2 & 30.8 & 12.9 & 9.5 & 8.4 \\
\hline GA & 30.6 & 34.0 & 1.11 & 46.5 & 53.6 & 29.1 & 20.5 & 4.0 & 67.7 & 28.2 & 0.42 & 62.2 & 37.9 & 17.9 & 11.5 & 8.5 \\
\hline
\end{tabular}

a Oc: oxygen bound to carbon.

b The binding energy of $\mathrm{C} 1 \mathrm{~s}$ at $284.6 \mathrm{eV}$ was assigned to $\mathrm{C}=\mathrm{C}, \mathrm{C}-\mathrm{C}$ and $\mathrm{C}-\mathrm{H}$, at $286.2 \mathrm{eV}$ to $\mathrm{C}-\mathrm{O}$, at $287.6 \mathrm{eV}$ to $\mathrm{C}=\mathrm{O}$, and at $289.1 \mathrm{eV}$ to $\mathrm{O}-\mathrm{C}=\mathrm{O}$.

${ }^{c}$ Sum of oxygen-containing functional groups.

${ }^{\text {d }}$ Incubation of new $\mathrm{BC}$ at $70{ }^{\circ} \mathrm{C}$ for 6 months.
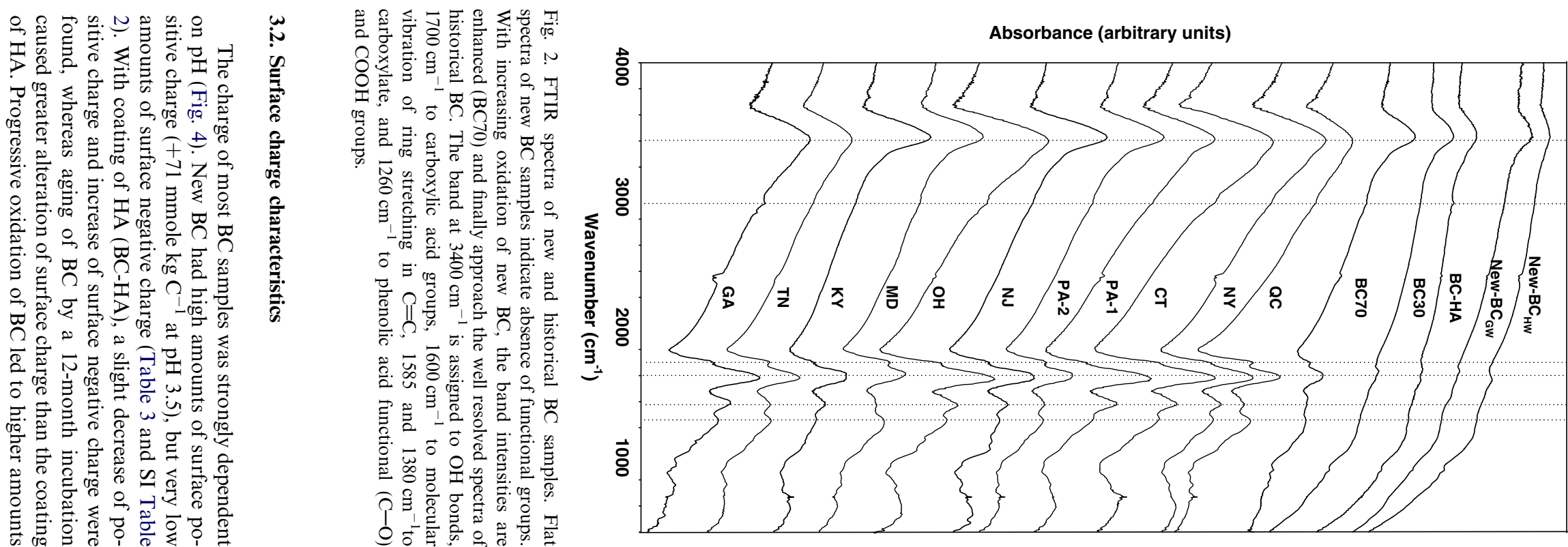


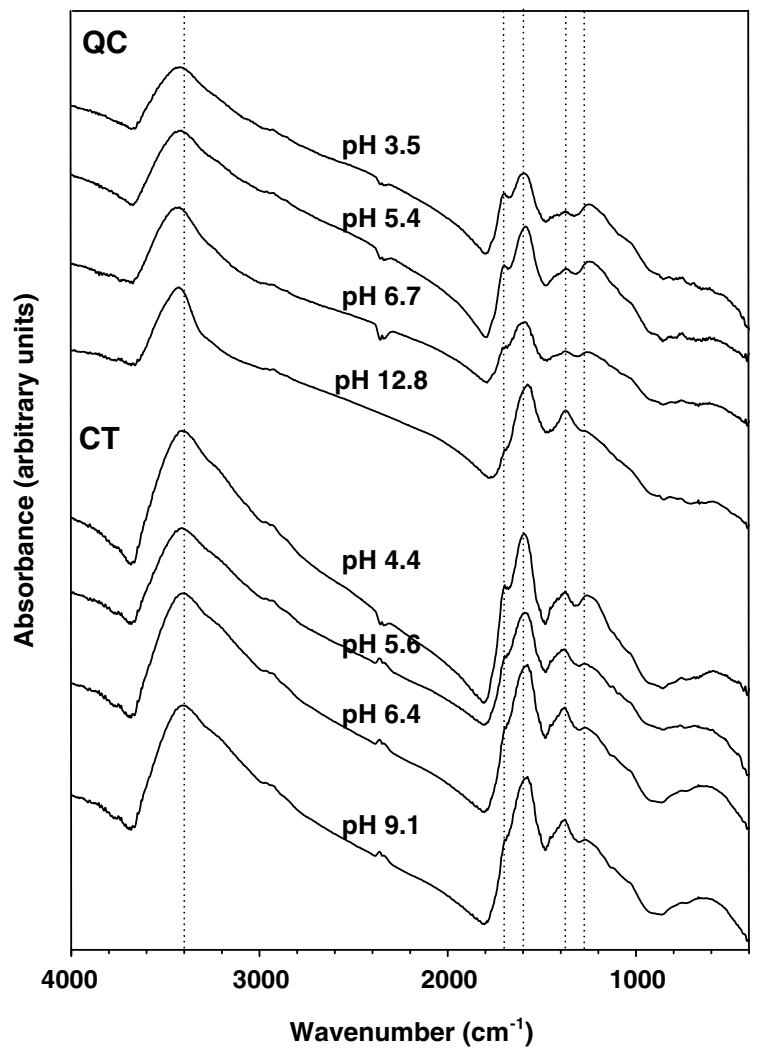

Fig. 3. FTIR spectra of the QC and CT BC samples at different $\mathrm{pH}$ values. Most bands are $\mathrm{pH}$ dependent and the band intensities at $1700 \mathrm{~cm}^{-1}$ (carboxylic groups) and $1260 \mathrm{~cm}^{-1}$ (carboxylic and phenolic groups) decrease with increasing $\mathrm{pH}$, while the bands intensities at $1585 \mathrm{~cm}^{-1}$ (carboxylate) and $1380 \mathrm{~cm}^{-1}$ (carboxylate) increase with increasing $\mathrm{pH}$.

of surface negative charge but lower amounts of surface positive charge, in which surface negative charge at $\mathrm{pH}$ 7.0 in $\mathrm{BC} 70$ was $201 \mathrm{mmole} \mathrm{kg} \mathrm{C}^{-1}$ and $\mathrm{BC} 30$ was 71 mmole $\mathrm{kg} \mathrm{C}^{-1}$ and surface positive charge in $\mathrm{BC} 70$ even diminished to zero. In contrast to new BC, all historical BC showed substantial amounts of surface negative charge and had an average surface negative charge of 1644 mmole $\mathrm{kg} \mathrm{C}^{-1}$ at $\mathrm{pH}$ 7.0. At the same time, no positive charge existed in historical $\mathrm{BC}$, which was similar to the results for $\mathrm{BC} 70$.

The PZNC of new BC was at pH 7.0 (Table 3). The PZNC of BC-HA slightly shifted to $\mathrm{pH} 6.8$, while the PZNC dropped to $\mathrm{pH} 3.4$ and 2.7 during aging of $\mathrm{BC}$ at 30 and $70^{\circ} \mathrm{C}$ for 12 months, respectively. Similar to the aged $\mathrm{BC}$, all historical $\mathrm{BC}$ samples showed acidic PZNC values of around $\mathrm{pH} 3$.

\subsection{Correlation between $\mathrm{BC}$ oxidation and climatic and soil characteristics}

Of all climatic and soil characteristics examined, MAT was the best predictor for BC oxidation (Table 4, and Fig. EA1). Based on simple linear regression, MAT significantly explained $84 \%$ of the variability of $C$ concentrations $(r=-0.92 ; P<0.01), 52 \%$ of the variability of $\mathrm{O}$ concen- trations $(r=0.72 ; P<0.01), 60 \%$ of the variability of atomic $\mathrm{O} / \mathrm{C}$ ratios $(r=0.78 ; P<0.01)$, and $69 \%$ of the variability of PCEC $(r=0.83 ; P<0.01)$ (Fig. 5a). Thus, lower $\mathrm{C}$ concentrations and higher $\mathrm{O}$ concentrations, $\mathrm{O} / \mathrm{C}$ ratios, and $\mathrm{PCEC}$ values were found for the $\mathrm{BC}$ samples from warmer areas. Effective CEC was significantly and positively correlated with soil $\mathrm{pH}$, which explained $70 \%$ of the variability $(r=0.85$ in average; $P<0.01)$, while no other correlation was found between $\mathrm{pH}$ and $\mathrm{BC}$ oxidation parameters. In addition, no other climatic or soil characteristic, such as MAP, effective precipitation (MAP-PET), $\mathrm{C} / \mathrm{N}$, clay content, or potential $\mathrm{C}$ mineralization, showed a significant correlation with $\mathrm{BC}$ oxidation.

MAT was better correlated with the Oc/C ratios of $\mathrm{BC}$ surfaces $(r=0.97 ; P<0.01)$ than with the $\mathrm{Oc} / \mathrm{C}$ ratios of entire BC particles $(r=0.67 ; P>0.05$; Fig. $5 \mathrm{~b})$. The Oc/C ratios of surfaces responded 7-fold stronger to increases in MAT than entire particles.

\section{DISCUSSION}

\subsection{Natural oxidation of $\mathrm{BC}$}

Our data clearly indicate that historical BC samples, representing a wide variety of geographic environments, are substantially oxidized after 130 years of exposure to soil. The van Krevelen diagram demonstrates the fundamental pathway of natural oxidation of BC (Fig. 1b), and indicates that the processes of natural oxidation of increasing both atomic $\mathrm{H} / \mathrm{C}$ and $\mathrm{O} / \mathrm{C}$ ratios display an opposite trend from pyrolytic processes (Shindo, 1991; Baldock and Smernik, 2002). It is also interesting to note that the $\mathrm{O} / \mathrm{C}$ ratios of humic acids extracted from charcoal (Trompowsky et al., 2006) and BC-containing soil (Haumaier and Zech, 1995) were significantly greater, while $\mathrm{H} / \mathrm{C}$ ratios of soils were similar and $\mathrm{H} / \mathrm{C}$ ratios of charcoal were lower than those of historical BC (Fig. 1b). Extracted humic acids from charcoal had an average $\mathrm{H} / \mathrm{C}$ ratio of 0.5 and $\mathrm{O} / \mathrm{C}$ ratio of 0.4 (Trompowsky et al., 2006), and BC-rich soils had an average $\mathrm{H} / \mathrm{C}$ ratio of 0.67 and $\mathrm{O} / \mathrm{C}$ ratio of 0.41 (Haumaier and Zech, 1995). Therefore, extractable HA from $\mathrm{BC}$ appeared to be more oxidized than the particulate $\mathrm{BC}$ studied here.

The differences between surface and bulk properties by XPS measurements highlight the fact that higher oxidative states were found on the surface region of BC particles relative to the interior (Brodowski et al., 2005; Lehmann et al., 2005; Liang et al., 2006). For the field BC samples, however, it is still difficult to unambiguously distinguish whether surface oxygen functional groups were due to adsorption of non-BC or the oxidation of BC itself. In our study, the significant relationship between MAT and surface atomic $\mathrm{O} / \mathrm{C}$ ratios may suggest a significant contribution from surface oxidation of $\mathrm{BC}$ itself rather than adsorption of non-BC (Fig. 5b). The lower increase in oxidation and PCEC by coating with HA than short-term incubation points in the same direction. On the long term, the exposure of $\mathrm{BC}$ in soils still resulted in considerable penetration of $\mathrm{BC}$ oxidation into the interior compared to new $\mathrm{BC}$ samples. 
The flat FTIR spectrum of new BC implies that the functional groups were completely eliminated during the charring processes (Nishimiva et al., 1998). With the oxidation of new $\mathrm{BC}$, the band intensities were enhanced through
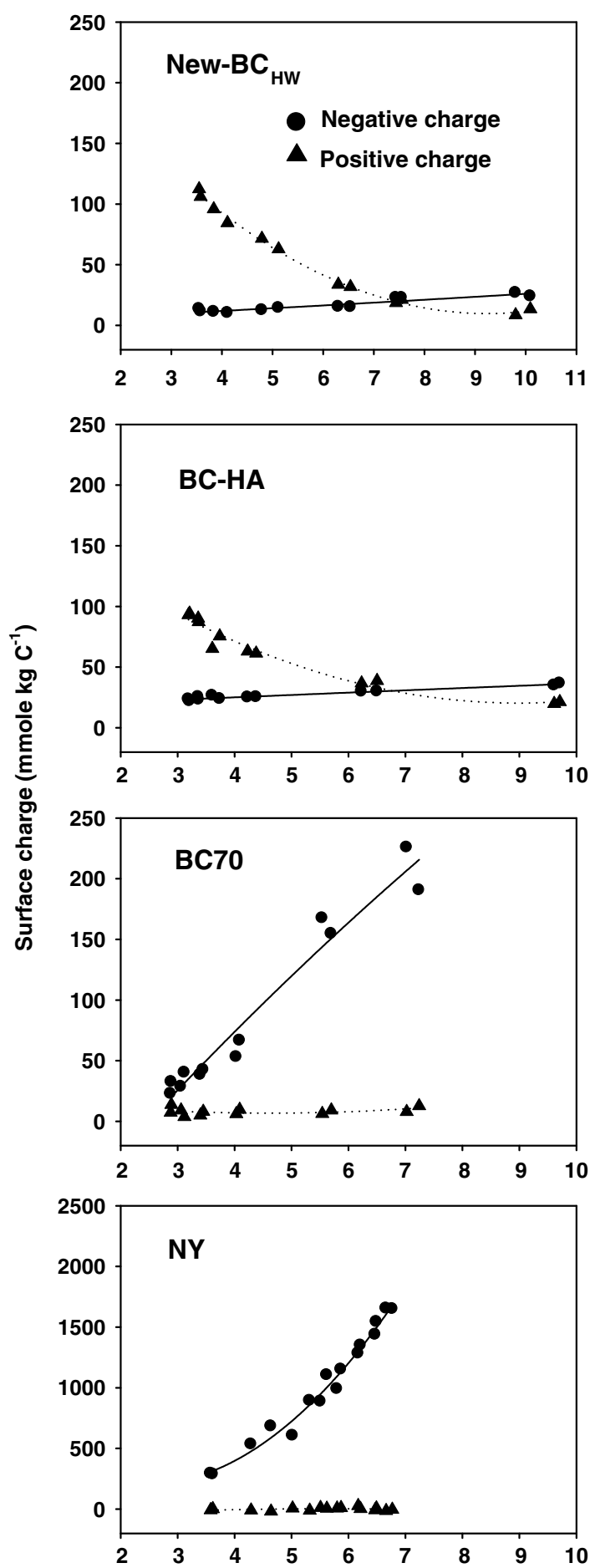

the introduction of dipole moments from forming functional groups (Starsinic et al., 1983; Morterra et al., 1984) and finally approached a well resolved spectrum, as shown by historical BC. The distribution of bands for the different
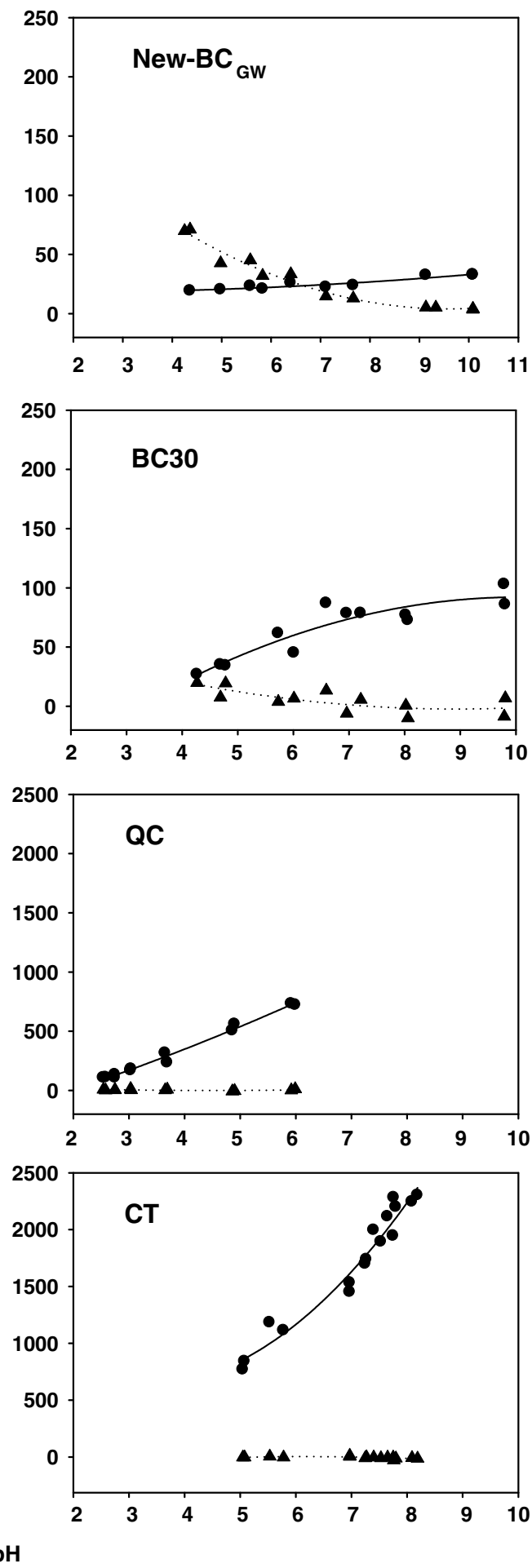

Fig. 4. The values of surface positive charge (triangles) and surface negative charge (circles) versus $\mathrm{pH}$ of new and historical $\mathrm{BC}$ samples. Quadratic regressions for surface positive charge and surface negative charge are shown with dotted and solid lines, respectively. Point of zero net charge (PZNC) is the $\mathrm{pH}$ of the intercept point between negative and positive charge curves. With progressive oxidation, positive charge decreases, negative charge increases, and PZNC shifts from $\mathrm{pH} 7$ in new $\mathrm{BC}$ to $\mathrm{pH} 3$ in historical $\mathrm{BC}$. Note the different scale of the y axes between new and historical $\mathrm{BC}$ samples. 

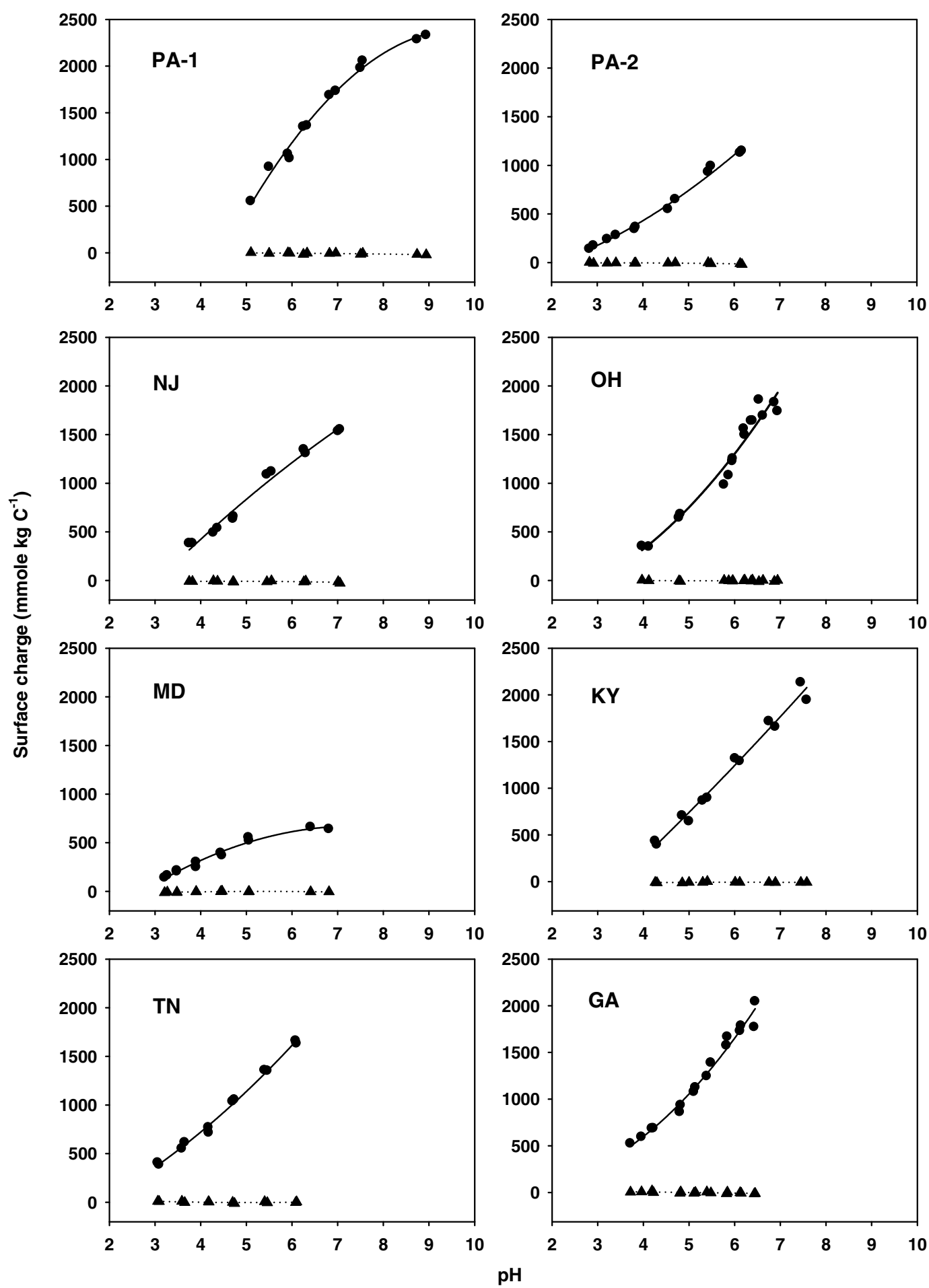

Fig. 4 (continued)

historical $\mathrm{BC}$ samples and therefore the main functional groups were similar, even though the BC samples were collected from different locations. Our results from XPS and FTIR directly indicate that the increase of $\mathrm{O}$ was not merely an adsorption of $\mathrm{O}$ to $\mathrm{BC}$ surfaces but a formation of oxygen-containing functional groups through natural oxidation of BC (Puri, 1970; Boehm, 1994). FTIR spectra suggest that carboxylic and phenolic functional groups were the dominant functional groups in the historical $\mathrm{BC}$ samples.

Formation of functional groups provides sites for surface negative charge. With progressive oxidation, surface negative charge of $\mathrm{BC}$ concurrently increased. Unlike new $\mathrm{BC}$ which contained $\mathrm{AEC}$, both $\mathrm{BC}$ incubated at $70^{\circ} \mathrm{C}$ and historical $\mathrm{BC}$ always exhibited $\mathrm{CEC}$ at any $\mathrm{pH}$ values above $\mathrm{pH}$ 3. Although aging of new $\mathrm{BC}$ at $70^{\circ} \mathrm{C}$ for 12 
Table 3

Point of zero net charge (PZNC), surface positive charge (AEC), effective cation exchange capacity (ECEC), potential cation exchange capacity (PCEC) of new BC and historical BC samples

\begin{tabular}{llllll}
\hline & PZNC & $\begin{array}{l}\mathrm{AEC} \mathrm{pH}_{3.5} \\
\left(\mathrm{mmole} \mathrm{kg}^{-1} \mathrm{C}\right)\end{array}$ & $\begin{array}{l}\mathrm{PCEC} \mathrm{pH}_{7.0} \\
\left(\mathrm{mmole} \mathrm{kg}^{-1} \mathrm{C}\right)\end{array}$ & $\begin{array}{l}\mathrm{ECEC} \mathrm{pH}_{\mathrm{H}_{2} \mathrm{O}} \\
\left(\mathrm{mmole} \mathrm{kg}^{-1} \mathrm{C}^{2}\right.\end{array}$ & $\begin{array}{l}\mathrm{ECEC} \mathrm{pH} \mathrm{KCl} \\
\left(\mathrm{mmole} \mathrm{kg}^{-1} \mathrm{C}\right)\end{array}$ \\
\hline New BC & $7.1(0.5)^{\mathrm{a}}$ & $+84^{\mathrm{b}}(20.7)$ & $+1.7(9.7)$ & $9.5(3.1)$ & $9.2(3.6)$ \\
BC-HA & 6.8 & +58 & 2 & +10 & +6 \\
BC30 & 3.4 & +18 & 71 & 85 & 83 \\
BC70 & 2.7 & $\mathrm{Nil}$ & 201 & 173 & 77 \\
Historical BC & $2.8(0.6)^{\mathrm{a}}$ & Nil & $1644(504)$ & $1125(424)$ & $668(410)$ \\
\hline
\end{tabular}

${ }^{\mathrm{a}}$ Standard deviation $(n=2$ for new $\mathrm{BC} ; n=11$ for historical $\mathrm{BC})$.

$\mathrm{b}+$ : net positive surface charge at the assigned $\mathrm{pH}$ value.

Table 4

Correlation coefficients between BC properties and the corresponding climatic and soil characteristics $(n=9)^{\mathrm{a}}$

\begin{tabular}{|c|c|c|c|c|c|c|}
\hline & $\mathrm{C}$ & $\mathrm{O}$ & Atomic $\mathrm{O} / \mathrm{C}$ & $\mathrm{PCEC}^{\mathrm{b}} \mathrm{pH}_{7.0}$ & $\mathrm{ECEC}^{\mathrm{c}} \mathrm{pH}_{\mathrm{H}_{2} \mathrm{O}}$ & $\mathrm{ECEC}^{\mathrm{c}} \mathrm{pH}_{\mathrm{KCl}}$ \\
\hline MAT & $-0.92^{\mathrm{f}}$ & $0.72^{\mathrm{f}}$ & $0.78^{\mathrm{f}}$ & $0.83^{\mathrm{f}}$ & 0.50 & 0.29 \\
\hline MAP & -0.52 & 0.41 & 0.44 & 0.37 & 0.00 & -0.05 \\
\hline MAP-PET & 0.37 & -0.27 & -0.29 & -0.50 & -0.54 & -0.31 \\
\hline Soil $\mathrm{pH}_{\mathrm{H}_{2} \mathrm{O}}$ & 0.09 & -0.22 & -0.33 & 0.11 & $0.87^{\mathrm{f}}$ & $0.89^{\mathrm{f}}$ \\
\hline Soil $\mathrm{pH}_{\mathrm{KCl}}$ & -0.02 & -0.35 & -0.23 & 0.21 & $0.73^{\mathrm{f}}$ & $0.91^{\mathrm{f}}$ \\
\hline Soil C/N & 0.13 & -0.34 & -0.30 & -0.04 & 0.08 & 0.10 \\
\hline Silt & -0.29 & $0.63^{\mathrm{e}}$ & 0.57 & 0.09 & -0.47 & -0.58 \\
\hline Clay & -0.58 & 0.54 & 0.55 & 0.43 & -0.04 & -0.03 \\
\hline $\mathrm{C}_{\min }{ }^{\mathrm{d}}$ & 0.01 & 0.17 & 0.14 & 0.04 & -0.06 & 0.02 \\
\hline
\end{tabular}

${ }^{a}$ PA-2 and MD sites were not included in the model due to different vegetation types.

b PCEC: potential cation exchange capacity.

${ }^{c}$ ECEC: effective cation exchange capacity.

${ }^{\mathrm{d}} \mathrm{C}_{\text {min }}$ : potential cumulative mineralized $\mathrm{C}\left(\mathrm{g} \mathrm{C}-\mathrm{CO}_{2}\right.$ per $\mathrm{kg}$ soil) for a 20 -day incubation at $30^{\circ} \mathrm{C}$.

e,f Significant correlation at $P$-value 0.05 and 0.01 , respectively.

months yielded a significant amount of CEC, the values were still much lower than by long-term natural oxidation as shown for the historical BC samples, which contained one order of magnitude greater CEC.

Concomitant to the increase of surface negative charge, surface positive charge decreased with progressive oxidation of BC and eventually disappeared. Similar results of decreasing surface positive charge through oxidation were also reported by Weller and Young (1948) and Papirer et al. (1987). Since the incorporation of O can localize $\pi$ electrons and reduce the capability of anion adsorption (Leon y Leon et al., 1992), the decline of positive charge and the shift of PZNC to lower $\mathrm{pH}$ occurred rapidly and was even faster than the massive buildup of surface charge. In our study, for example, AEC and PZNC of $\mathrm{BC}$ incubated at $30^{\circ} \mathrm{C}$ rapidly dropped from 84 mmole $\mathrm{kg} \mathrm{C}^{-1}$ for $\mathrm{New}-\mathrm{BC}_{\mathrm{HW}}$ to 18 mmole $\mathrm{kg} \mathrm{C}^{-1}$ and from $\mathrm{pH} 7.1$ to $\mathrm{pH} 3.4$, respectively; while PCEC only increased from +1.7 to 71 mmole $\mathrm{kg} \mathrm{C}^{-1}$. These values were much lower than the high CEC values when fresh $\mathrm{BC}$ was incubated at $70{ }^{\circ} \mathrm{C}$ or the $\mathrm{CEC}$ values of historical $\mathrm{BC}$ samples.

\subsection{Adsorption of non-BC materials}

With the coating of new BC by HA, surface negative charge slightly increased and surface positive charge and
PZNC slightly decreased. Similar results have also been reported by Rivera-Utrilla et al. (2001). However, our data showed that the extent of change of BC properties by coating with HA were significantly lower than those by the oxidation of $\mathrm{BC}$ itself, especially compared to oxidized BC samples, such as BC70. From a long-term perspective, oxidation of $\mathrm{BC}$ itself was therefore more likely to influence $\mathrm{BC}$ properties rather than the adsorption of non-BC materials.

\subsection{Effects of climatic and soil characteristics on BC oxidation}

To our knowledge, this study is the first to compare the temperature dependence of long-term BC oxidation in soils across a wide geographic range. Although the long duration of time is an important cause for the high level of natural oxidation of $\mathrm{BC}, \mathrm{BC}$ oxidation is significantly related to increasing MAT. Our data even suggest that temperature had a greater effect on BC oxidation than the time of exposure to soil. Enhanced BC oxidation (Puri, 1961; Cheng et al., 2006) and irreversible chemisorption of oxygen by char (Allardice, 1966) at higher temperatures have been reported in laboratory experiments and coincide well with our results on the natural oxidation of BC in soils. Our study further indicates that higher MAT increased the surface negative charge by 87 mmole $\mathrm{kg} \mathrm{C}^{-1}$ for each degree Cel- 

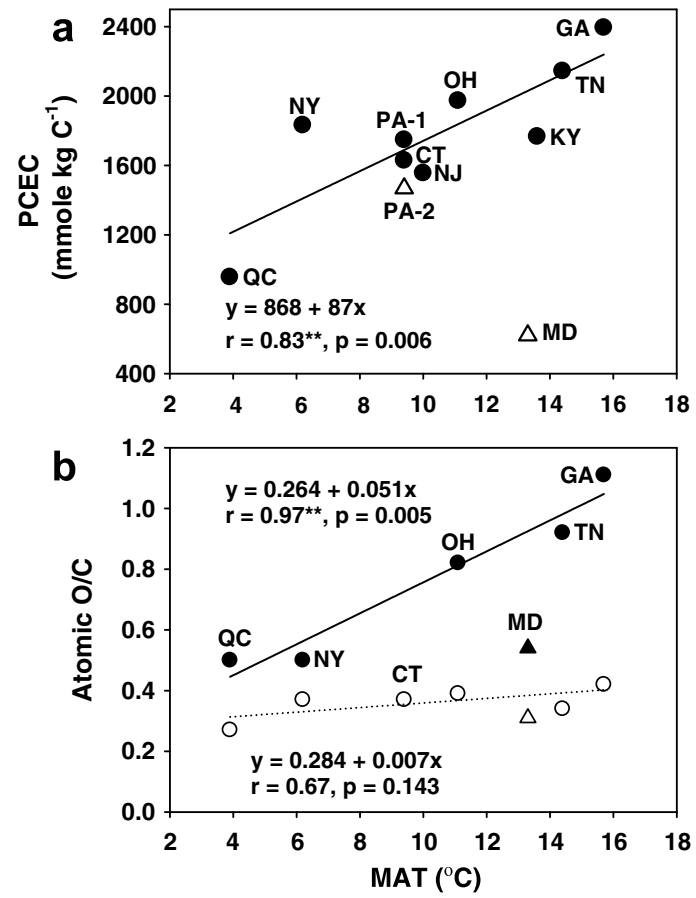

Fig. 5. (a) The relationship between mean annual temperature (MAT) and potential cation exchange capacity (PCEC) $(n=9)$; (b) the relationship between MAT and atomic $\mathrm{O} / \mathrm{C}$ ratios measured by $\mathrm{X}$-ray photoelectron spectroscopy (XPS) $(n=6)$, for surface (filled circles) and bulk data (open circles) of the historical BC samples. Triangles in both (a) and (b) denote sites under conifer vegetation (PA-2 and MD), which were excluded from the regression.

sius (Fig. 5a) and CEC ranges from 956 mmole $\mathrm{kg} \mathrm{C}^{-1}$ in Quebec to 2354 mmole $\mathrm{kg} \mathrm{C}^{-1}$ in Georgia. This very large negative charge is related to an oxidation of surfaces of $\mathrm{BC}$ which increases with greater temperature but has much lower effects on entire BC particles (Fig. 5b).

In contrast to the general understanding of weathering of mineral matter in soil which results in greater surface positive charge and higher PZNC with greater MAT as exemplified in tropical soils (Marcano-Martinez and McBride, 1989; Chorover and Sposito, 1995), higher MAT enhanced surface negative charge and oxidation lowered PZNC of BC. Since considerable amounts of CEC can be generated by $\mathrm{BC}$, the presence of $\mathrm{BC}$ can even exceed the $\mathrm{AEC}$ in tropical soils. Consequently, high $\mathrm{CEC}$ was reported in tropical BC-containing soils, despite the fact that these soils contained highly weathered minerals (Liang et al., 2006).

The ECEC of the historical BC samples was positively correlated with $\mathrm{pH}$ values. These observations reinforce the findings that $\mathrm{BC}$ contains $\mathrm{pH}$-dependent variable charge and that the in-situ ionization of $\mathrm{BC}$ directly depends on soil $\mathrm{pH}$ values. In archaeological research, Cohen-Ofri et al. (2006) found that self-humification of BC can be accelerated in soils with basic environments. However, it was not observed that $\mathrm{pH}$ influenced molecular structure and potential surface charge of $\mathrm{BC}$, since there was no relationship between $\mathrm{pH}$ and the parameters of $\mathrm{BC}$ oxidation in our data set. The furnace sites of PA-2 and MD under conifer vegetation excluded from our calculation may require further investigation for their low oxidation and low $\mathrm{pH}$ values in order to understand the possible direct and indirect effects of $\mathrm{pH}$ and vegetation types on $\mathrm{BC}$ oxidation.

Although occlusion of small BC particles $(<250 \mu \mathrm{m})$ inside aggregates or interactions with mineral surfaces were suspected to reduce BC oxidation (Glaser et al., 2000; Brodowski et al., 2005), no correlation was found between soil texture and $\mathrm{BC}$ oxidation in this study. This disparity may be due in part to the large size of $\mathrm{BC}$ fragments used in this study, which may reduce the interactions between $\mathrm{BC}$ and minerals. However, it is more likely that the wide range of MAT studied in this experiment masked the effects of soil texture on $\mathrm{BC}$ oxidation, and that a targeted research design is required to study soil texture effects. In addition, there was no correlation between soil organic matter quality or potential biological activity, such as soil $\mathrm{C} / \mathrm{N}$ ratios and potential $\mathrm{C}$ mineralization, and $\mathrm{BC}$ oxidation. This finding may indicate that microbiological activity was not controlled to a different extent by substrate quality between BC-containing soils at different MAT. Differences in oxidation can then be explained by MAT and may not be limited by substrate quality.

\subsection{Environmental significance}

In natural ecosystems, evolution of negative charge may be an important ecological change of $\mathrm{BC}$ after forest or savanna fires. Annual BC production is estimated to be 50 $270 \mathrm{Tg} \mathrm{yr}^{-1}$, with a major source coming from vegetation fires (Kuhlbusch and Crutzen, 1995; Forbes et al., 2006). Unlike the BC samples used in this study that were produced at high temperature $\left(>500^{\circ} \mathrm{C}\right.$ ) (Hollingdale et al., 1999), BC from vegetation fire is generally produced at lower temperature (below $450{ }^{\circ} \mathrm{C}$ ) (Chandler et al., 1983). Puri (1961) proposed that oxidation rates increase for $\mathrm{BC}$ produced at lower charring temperatures. It can be anticipated that most naturally produced $\mathrm{BC}$ should undergo more rapid oxidation than the BC samples used in this study.

Through natural oxidation in soil, the purposeful application of $\mathrm{BC}$ (often called biochar in this context) may evolve into a management tool to increase nutrient retention (Lehmann, 2007a,b). Production temperatures of about $450-600{ }^{\circ} \mathrm{C}$ reached in modern pyrolysis facilities for bioenergy and concurrent biochar production are similar to the ones reported for traditional kilns, and the information obtained from the present experiment provides guiding principles for the behaviour of biochar when applied to soil (Lehmann, 2007a,b). Lehmann et al. (2003) showed that BC-containing soils decreased the leaching of applied ammonium and that leaching of $\mathrm{Ca}$ was lower despite greater plant availability of $\mathrm{Ca}$. High $\mathrm{CEC}$ is also an important reason for the high soil fertility in Amazon Dark Earths (Terra preta), where BC was deposited in pre-Columbian periods (Glaser et al., 2001). However, the relatively low oxidation and PCEC of incubated $\mathrm{BC}$ in comparison to 130-year old BC (this study) as well as the BC of Dark Earths with ages of up to several thousand years (Liang et al., 2006) still bears the question what the minimum time and temperature conditions are that generate high CEC on $\mathrm{BC}$. 
BC persists in soils for long periods of time, typically showing radiocarbon ages that are older than the most stable non-BC fractions in soils (Pessenda et al., 2001; Krull et al., 2006), and have been dated to originate from fire hundreds to thousands of years ago (Preston and Schmidt, 2006). Thus, BC found in soil is expected to be highly oxidized after such long-term exposure to natural oxidation processes. Oxidation of BC through both short- and longterm natural oxidation may therefore play an important role in the global $\mathrm{BC}$ cycles and in the effects of $\mathrm{BC}$ on soil biogeochemistry.

\section{CONCLUSION}

This paper reports substantial oxidation of $\mathrm{BC}$ in soils over a 130 year period, greatly exceeding oxidation by short-term laboratory incubation or by adsorption of organic matter. The principle oxidation processes of $\mathrm{BC}$ included: (1) increase of $\mathrm{O}$ and $\mathrm{H}$ and decrease of $\mathrm{C}$, (2) formation of O-containing functional groups, and (3) decrease of surface positive charge and evolution of surface negative charge. While oxidation of $\mathrm{BC}$ significantly increased over time, it was also significantly modified by temperature, increasing with higher MAT. However, the dynamics of the development of oxidation and exchange sites and temperature sensitivity over time periods of decades still remain unclear. Future research should also address in what way soil clay content, clay mineralogy and $\mathrm{pH}$ influences the dynamics and temperature sensitivity of $\mathrm{BC}$ oxidation.

\section{ACKNOWLEDGEMENTS}

We thank the Forges du Saint-Maurice National Historic Site (QC), Katahdin Iron Wroks (ME), Town of Port Henry (NY), The Friends of Beckley Furnace (CT), Greenwood Furnace State Park (PA), Hopewell Furnace National Historical Site, Oxford Furnace (NJ), The Ohio Historical Society $(\mathrm{OH})$, Nassawango Iron Furnace (MD), Montgomery Bell State Park (TN), Iron Station (NC), Cooper's Iron Works (GA) for permission us to take the soil and BC samples. We also thank Pierre Drouin, Daniel Toutant, Dr. Tom Desjardin, Joan Daby, Walter Rushby, Walt Landgraf, Paul Fagley, Kathy Fisher, Dan Reese, Steven Ambrose, Feil Norman, Cary Lyle, Carey Tichenor, Dr. John White, Dr. Alan May, Vicki Gentry, and Chang-Ya Chen for their help in the field work. The XPS measurements were performed in the Environmental Molecular Sciences Laboratory, a national scientific user facility, located at Pacific Northwest National Laboratory, WA. We also thank Dr. Keith Eggleston at Cornell University for providing the climate data and Dr. Shree Gami for technical support. We are very grateful for financial supports by the Ministry of Education in Taiwan, the Henry Wu Scholarship, the Kieckhefer Adirondack Fellowship, the Biogeochemistry and Environmental Biocomplexity small grant, and the Upper Susquehanna Agricultural Ecology Program mini-grant of Cornell University, and the Graduate Student Research Grants of the Geological Society of America to C.H.C.

\section{APPENDIX A. SUPPLEMENTARY DATA}

Elemental composition and $\mathrm{pH}$ values of $\mathrm{BC}$ samples (Table EA1), surface charge values of BC (Table EA2) and the linear regression of $\mathrm{BC}$ properties and environmental factors (Fig. EA1) are presented as online supporting material. This material is available free of charge via the Internet at http://www.sciencedirect.com/science/journal/ 00167037. Supplementary data associated with this article can be found, in the online version, at doi:10.1016/ j.gca.2008.01.010.

\section{REFERENCES}

Allardice D. J. (1966) The adsorption of oxygen on brown coal char. Carbon 4, 255-266.

Baldock J. A. and Smernik R. J. (2002) Chemical composition and bioavailability of thermally, altered Pinus resinosa (Red pine) wood. Org. Geochem. 33, 1093-1109.

Bining A. C. (1938) Pennsylvania Iron Manufacture in the Eighteenth Century. Pennsylvania Historical Commission, Harrisburg, Pennsylvania.

Billinge B. H. M. and Evans M. G. (1984) The growth of surface oxygen complexes on the surface of activated carbon exposed to moist air and their effect on methyl iodide-131 retention. $J$. de Chimie Physique 81, 779-784.

Bird M. I., Moyo C., Veenedaal E. M., Lloyd J. and Frost P. (1999) Stability of elemental carbon in a savanna soil. Global Biogeochem. Cycles 13, 923-932.

Boehm H. P. (1994) Some aspects of surface chemistry of carbon blacks and other carbons. Carbon 32, 759-770.

Brodowski S., Amelung W., Haumaier L., Abetz C. and Zech W. (2005) Morphological and chemical properties of black carbon in physical soil fractions as revealed by scanning electron microscopy and energy-dispersive X-ray spectroscopy. Geoderma 128, 116-129.

Chandler C., Cheney P., Thomas P., Trabaud L. and Williams D. (1983) Fire in forestry.

Cheng, C.H. (2008). Oxidation of black carbon in soils. Ph.D. thesis. Cornell University.

Cheng C. H., Lehmann L., Thies J. E., Burton S. D. and Engelhard M. H. (2006) Oxidation of black carbon through biotic and abiotic processes. Org. Geochem. 37, 1477-1488.

Clark J. S. and Royall R. D. (1995) Particle-size evidence for source areas of charcoal accumulation in late Holocene sediments of eastern North American lakes. Quart. Res. 43, 80-89.

Chorover J. and Sposito G. (1995) Surface charge characteristics of kaolinitic tropical soils. Geochim. Cosmochim. Acta 59, 875884.

Chorover J., Amistadi M. K. and Chadwick O. A. (2006) Surface charge evolution of mineral-organic complexes during pedogenesis in Hawaiian basalt. Geochim. Cosmochim. Acta 68, 4859-4876.

Cohen-Ofri I., Weiner L., Boaretto E., Mintz G. and Weiner S. (2006) Modern and fossil charcoal: aspects of structure and diagenesis. J. Archae. Sci. 33, 428-439.

Czimczik C. I. and Masiello C. A. (2007) Controls on black carbon storage in soils. Global Biogeochem. Cycles 21, GB3005. doi:10.1029/2006GB002798.

Davidson E. A. and Janssens I. A. (2006) Temperature sensitivity of soil carbon decomposition and feedbacks to climate change. Nature 440, 165-173.

Forbes M. S., Raison R. J. and Skjemstad J. O. (2006) Formation, transformation and transport of black carbon (charcoal) in terrestrial and aquatic ecosystems. Sci. Tot. Environ. 370, 190 206.

Glaser B., Balashov E., Haumaier L., Guggenberger G. and Zech W. (2000) Black carbon in density fractions of anthropogenic soils of the Brazilian Amazon region. Org. Geochem. 31, 669-678. 
Glaser B., Haumaier L., Guggenberger G. and Zech W. (2001) The'Terra Preta' phenomenon: a model for sustainable agriculture in the humid tropics. Naturwissenschaften 88, 3741.

Goldberg E. D. (1985) Black Carbon in the Environment. John Wiley, New York.

Guo Y. and Bustin R. M. (1998) FTIR spectroscopy and reflectance of modern charcoals and fungal decayed woods: implications for studies of inertinite in coals. Coal Geol. 37, 2953.

Hamer U., Marschner B., Brodowski S. and Amelung W. (2004) Interactive priming of black carbon and glucose mineralization. Org. Geochem. 35, 823-830.

Haumaier L. and Zech W. (1995) Black carbon-possible source of highly aromatic components of soil humic acids. Org. Geochem. 23, 191-196.

Hockaday W. C., Grannas A. M., Kim S. and Hatcher P. G. (2006) Direct molecular evidence for the degradation and mobility of black carbon in soils from ultrahigh-resolution mass spectral analysis of dissolved organic matter from a fire-impacted forest soil. Org. Geochem. 37, 501-510.

Hollingdale A. C., Krishana R. and Robinson A. P. (1999) Charcoal Production - A Handbook. eco-logic books, Bristol.

Jia Y. F. and Thomas K. M. (2000) Adsorption of cadmium ions on oxygen surface sites in activated carbon. Langmuir 16, 1114 1122.

Knicker H. (2007) How does fire affect the nature and stability of soil organic nitrogen and carbon? A review. Biogeochemistry $\mathbf{8 5}$, 91-118.

Krull E. S., Swanston C. W., Skjemstad J. O. and McGowan J. A. (2006) Importance of charcoal in determining the age and chemistry of organic carbon in surface soils. J. Geophys. Res. 111, G04001.

Kuhlbusch T. A. J. and Crutzen P. J. (1995) Toward a global estimate of black carbon in residues of vegetation fires representing a sink of atmospheric $\mathrm{CO}_{2}$ and a source of $\mathrm{O}_{2}$. Global Biogeochem. Cycles 9, 491-501.

Lehmann J. (2007a) A handful of carbon. Nature 447, 143-144.

Lehmann J. (2007b) Bio-energy in the black. Front. Ecol. Environ. 5, 381-387.

Lehmann J., Pereira da Silva, Jr., J., Steiner C., Nehls T., Zech W. and Glaser B. (2003) Nutrient availability and leaching in an archaeological Anthrosol and a Ferrasol of the central Amazon basin: fertilizer, manure and charcoal amendments. Plant Soil 249, 343-357.

Lehmann J., Liang B., Solomon D., Lerotic M., Luizão F., Kinyangi J., Schäfer T., Wirick S. and Jacobsen C. (2005) Nearedge X-ray absorption fine structure (NEXAFS) spectroscopy for mapping nano-scale distribution of organic carbon forms in soil: application to black carbon particles. Global Biogeochem. Cycles 19, GB1013.

Lehmann J., Gaunt J. and Rondon M. (2006) Bio-char sequestration in terrestrial ecosystems-a review. Mit. Adapt. Strat. Global Change 11, 403-427.

Leon y Leon C. A., Solar J. M., Calemma V. and Radovic L. R. (1992) Evidence for the protonation of basal plane sites on carbon. Carbon 30, 797-811.

Liang B., Lehmann J., Solomon D., Kinyangi J., Grossman J., O’Neill B., Skjemstad J. O., Thies J., Luizao F. J., Petersen J. and Neves E. G. (2006) Black carbon increases cation exchange capacity in soils. Soil Sci. Soc. Am. J. 70, 1719-1730.
Marcano-Martinez E. and McBride M. B. (1989) Comparison of the titration and ion adsorption methods for surface charge measurement in oxisols. Soil Sci. Soc. Am. J. 54, 1040-1045.

Morterra C., Low M. J. D. and Severdia A. G. (1984) IR studies of carbon. 3. The oxidation of cellulose chars. Carbon 22, 5-12.

Nishimiva K., Hata T., Imamur Y. and Ishihara S. (1998) Analysis of chemical structure of wood charcoal by X-ray photoelectron spectroscopy. J. Wood Sci. 44, 56-61.

Papirer E., Li S. and Donnet J. (1987) Contribution to the study of basic surface groups on carbons. Carbon 25, 243-247.

Pessenda L. C. R., Gouveia S. E. M. and Aravena R. (2001) Radiocarbon dating of total soil organic matter and humin fraction and its comparison with $14 \mathrm{C}$ ages of fossil charcoal. Radiocarbon 43, 595-601.

Preston C. M. and Schmidt M. W. I. (2006) Black (pyrogenic) carbon: a synthesis of current knowledge and uncertainties with special consideration of boreal regions. Biogeoscience 3, 397420.

Proctor A. and Sherwood P. (1982) XPS studies of carbon fiber surface. Surf. Interf. Anal. 4, 212-219.

Puri, B.R. (1961). Surface oxidation of charcoal at ordinary temperatures. In Proceeding of the 5th Carbon Conference, pp. $165-170$.

Puri B. R. (1970) Surfaces complexes on carbons. In Chemistry and Physics of Carbon (ed., Jr. P. L. Walker). Marcel Dekker, New York, pp. 191-282.

Rivera-Utrilla J., Bautista-Toledo I., Ferro-Garcia M. A. and Moreno-Castilla C. (2001) Activated carbon surface modifications by adsorption of bacteria and their effect on aqueous lead adsorption. J. Chem. Technol. Biotechnol. 76, 1209-1215.

Rolando V. R. (1992) 200 Years of Soot and Sweat: The History and Archeology of Vermont's Iron, Charcoal, and Lime Industries. Vermont Archaeological Society, Machester Center, Vermont.

Rumpel C., Chaplot V., Planchon O., Bernadou J., Valentin C. and Mariotti A. (2006) Preferential erosion of black carbon contribution on steep slopes with slash and burn agriculture. Catena 65, 30-40.

Schmidt M. W. I. and Noack A. G. (2000) Black carbon in soils and sediments: analysis, distribution, implications, and current challenges. Global Biogeochem. Cycles 14, 777-793.

Shindo H. (1991) Elementary composition humus composition and decomposition in soil of charred grassland plants. Soil Sci. Plant Nutri. 38, 31-41.

Starsinic M., Taylor R. L., Walker, Jr., P. L. and Painter P. C. (1983) FTIR studies of Saran chars. Carbon 21, 69-74.

Trompowsky P. M., de Melo Benites V., Madari B. E., Pimenta A. S., Hockaday W. C. and Hatcher P. G. (2006) Characterization of humic like substances obtained by chemical oxidation of eucalyptus charcoal. Org. Geochem. 36, 1480-1489.

Uehara G. and Gillman G. (1981) The Mineralogy, Chemistry, and Physics of Tropical Soils with Variable Charge Clays. Westview Press, Boulder, CO.

Warren K. (1973) The American Steel Industry, 1850-1970: A Geographic Interpretation. Oxford University Press, London.

Weller S. and Young T. F. (1948) Oxygen complexes on charcoal. J. Amer. Chem. Soc. 70, 4155-4162. 